increases with the age of the child, and that it is poor under 4 months of age (Chanock et al., 1961). As already noted, six out of eight children in this trial who had no serological response to respiratory syncytial virus antigen were 12 weeks old or less. Other viruses have also been implicated in respiratory disorders of infants (Clarke, Corner, Gambier, Macrae, and Peacock, 1964 ; Gardner et al., 1964 ; Holzel et al., 1965), but the fact that 10 out of 18 cases showed a fourfold rise in titre to respiratory syncytial virus, and that all cases had very similar symptoms and occurred in an epidemic, would strongly suggest that most cases were due to infection with respiratory syncytial virus.

It is evident that ampicillin did not influence recovery of children with bronchiolitis in this trial. Patients with this disorder are often treated with antibiotics in the belief that these will at least prevent secondary infection (Heycock and Noble, 1962). The only evidence for this in the present series was in one case of otitis media. The duration of symptoms and signs was very similar to that found in previous cases treated by us with other wide-spectrum antibiotics, suggesting that had they been used in the trial instead of ampicillin the results would have been the same.

It is rare in domiciliary practice and uncommon in hospital to find infants with bronchiolitis who are not being treated with antibiotics. The results of this trial would suggest that their use does not hasten recovery. Apart from the question of cost the use of unnecessary antibiotics may not only cause iatrogenic illness but may increase the number of drug-resistant organisms. It is suggested that, in epidemic bronchiolitis of infants, antibiotics are used more to treat the physician's peace of mind than the patient's disease.

\section{Summary}

A double-blind study of the effect of ampicillin in an outbreak of bronchiolitis was carried out on 52 patients. Eight were removed from the trial because of complications. In the 25 treated with ampicillin and the 19 given a placebo there was no significant difference in the duration of symptoms and signs.

Respiratory syncytial virus was shown to be the cause of infection in 10 out of 18 patients investigated. There were no deaths in the trial.

We would like to thank Professor O. L. Wade and Dr. P. C Elmes, of the Department of Therapeutics, Queen's University, Belfast, for advice and encouragement. Beechams Research Laboratories kindly supplied both the ampicillin and the placebo.

\section{REFERENCES}

Beem, M., Wright, F. H., Hamre, D., Egerer, R., and Oehme, M. (1960) New Engl. F. Med., 263, 523.

Chanock, R. M., Kim, H. W., Vargosko, A. J., Deleva, A., Johnson, K. M., Cumming, C., and Parrot, R. H. (1961). 7. Amer. med. Ass., K. M., C 647 .

Clarke, S. K. R., Corner, B. D., Gambier, D. M., Macrae, J., and Peacock, D. B. (1964). Brit. med. F., 1, 1536.

Connolly, J. H., Forsyth, J. R. L., Haire, M., Evans, J., and White, B. (1963). Ulster med. F., 32, 192.

Elliot, R. B., Stokes, E. J., and Maxwell, G. M. (1964). Arch. Dis. Childh., 39, 101 .

Gardner, P. S., Elderkin, F. M., and Wall, A. HI. (1964). Brit. med. J., 2,1570 .

Heycock, J. B., and Noble, T. C. (1962). Ibid., 2, 879.

Holt, L. E., McIntosh, R., and Barnett, H. L. (1962). Paediatrics, 13th ed. Appleton-Century-Crofts, New York.

Holzel, A., Parker, L., Patterson, W. H., Cartmel, D., White, L. L. R., Purdy, R., Thompson, K. M., and Tobin, J. O'H. (1956). Brit. med. f., 1, 614 . med. J., White, L. L. R., Thompson, K. M., and Tobin, J. O'H. (1963). Lancet, 1, 295.

Jolly, H. (1964). Diseases of Children. Blackwell, Oxford.

McClelland, L. Hilleman, M. R. Hamparian, V. V., Ketler, A., Reilly, C. M., Cornfeld, D., and Stokes, J. (1961). New Engl. F. Med., 264, 1169.

Ross, C. A. C., Stott, E. J., McMichael, S., and Crowther, I. A. (1964) Arch. ges. Virusforsch., 14, 553.

Sandiford, B. R., and Spencer, B. (1962). Brit. med. f., 2, 881.

Shirkey, H. C. (1964). Paediatric Therapy. Mosby, St. Louis.

Wallman, I. S., and Hilton, H. B. (1962). Lancet, 1, 827,

\title{
Catatonic Stupor in Elderly Woman with Hyperparathyroidism
}

\author{
T. D. R. HOCKADAY,* B.M., M.R.C.P. ; W. M. KEYNES, † M.D., M.CHIR., F.R.C.s. ; \\ J. K. MCKENZIE,* M.D., M.R.C.P., M.R.A.C.P.
}

Brit. med. F., 1966, 1, 85-87

The patient whose case is reported below presented in a manner not previously described in hyperparathyroidism nor, indeed, in hypercalcaemia. One of the oldest patients from whom a parathyroid adenoma has been removed during life, she presented an interesting differential diagnosis between hyperparathyroidism and hypercalcaemia from immobility in Paget's disease.

\section{Case History}

A widow aged 75 was admitted to hospital under the care of Sir George Pickering because one morning she had been found in bed, apparently unconscious. Many notes were scattered about the room, and most were attempts at making a will. There was no evidence that she had taken any tablets or had suffered a recent injury. Her daughter, who lived near, said that her \footnotetext{
* Department of the Regius Professor of Medicine, Radcliffe Infirmary,
Oxford.

† Nuffield Department of Surgery, Radcliffe Infirmary, Oxford.
}

mother had been behaving strangely for some four weeks before admission. The most florid example was when she wrote some cheques for large sums of money that she did not possess. Her letters and conversation were sometimes confused. Three months before admission she had fallen, with loss of consciousness for a few moments, but quickly recovered except for some unsteadiness in walking. A week before admission the daughter went away on holiday, and received three curiously phrased letters from her mother.

About eight years ago she had complained for a few weeks of leg and back pain and of difficulty in walking. These symptoms did not recur until a few months before the present admission. She then attended an orthopaedic hospital, where osteoarthritis of both hips and Paget's disease of the pelvis were diagnosed, and she was provided with two sticks and a surgical belt.

Her weight had been steady in recent years. She had been constipated for at least eight years, and this had recently become an increasing problem. For about two years she had felt unduly thirsty, but her daughter had not noticed that she drank excessively. There had been no notable change in skin, hair, or nails. She had no personal or family history of mental illness. Since leaving her 
old home two years previously she said she had felt less cheerful, though her daughter had not thought her mother to be depressed.

On admission the patient lay torpid, and was active only in occasionally asking for a drink and in resisting examination-for example, by screwing up her eyes when an attempt was made to open them. Though her tongue was dry she was not generally dehydrated. She was catatonic: her arms would maintain any posture imposed on them.

Her pulse was $100 / \mathrm{min}$. in sinus rhythm, and her oral temperature $97.2^{\circ}$ F. $\left(36.2^{\circ}\right.$ C.). Blood-pressure was $140 / 80 \mathrm{~mm}$. $\mathrm{Hg}$. There was no evidence of cardiac failure. The abdomen was normal except that the symphysis pubis seemed enlarged as a smooth, hard, bony swelling. Examination of the central nervous system was made difficult by her mental state, but neither focal nor other general abnormality was detected in it. She responded very little to painful stimuli, except by changes in respiration and pulse. The fundi appeared normal, though they were not easy to see because of an early senile cataract in each lens. There was no incontinence. The femora were slightly bowed laterally, but the tibiae and clavicles appeared normal and not unusually warm. There were no deposits of calcium in the cornea or global conjunctivae. There was no palpable swelling in the neck; barium swallow examination could not be satisfactorily performed because of the patient's mental condition.

\section{Investigations}

The urine was of normal specific gravity, without excess of protein, glucose, or urobilinogen. Haemoglobin was $106 \%$ (15.4 g./ $100 \mathrm{ml}$.) and W.B.C. were $10,800 / \mathrm{c}$. mm., with a mild polymorphonuclear leucocytosis. There were normal plasma concentrations of sodium, chloride, and bicarbonate, but the potassium concentration was $3.0 \mathrm{mEq} / 1$. The cerebrospinal fluid was obtained at a normal pressure and contained 2 lymphocytes $/ \mathrm{c} . \mathrm{mm}$. and $55 \mathrm{mg}$. of protein per $100 \mathrm{ml}$. Chest $x$-ray examination showed possible old tuberculous activity in the upper zone of the right lung. Skull $x$-ray examination revealed a central pineal body, an intact pituitary fossa, and a thickened mottled calvaria like that seen in Paget's disease. The pubic rami were so curved that their medial ends were abnormally opposed to form the palpable bony tumour.

The rapid onset of so curious a mental state for the first time in this elderly woman warranted further investigation. Electroencephalography showed a generalized abnormality with diffusely distributed slow waves but also a considerable amount of alpha-like activity. No air entered the ventricular system on lumbar encephalography, but air in the cisterns showed the midline structures to be central. The callosal and ambient cisterns were very large, and excessive cortical air indicated marked generalized atrophy, which was confirmed by air ventriculography. This also showed dilated lateral ventricles, while the ventricular fluid was normal in pressure and composition.

The first plasma calcium determination next became available; it was markedly raised at $14.6 \mathrm{mg} . / 100 \mathrm{ml}$. and was followed by other values of 14.0 and $13.2 \mathrm{mg}$. The corresponding plasma inorganic phosphate concentrations were $2.0,2.2$, and $2.4 \mathrm{mg}$./ $100 \mathrm{ml}$. respectively. Plasma alkaline phosphatase was $80 \mathrm{King}$ Armstrong units. $X$-ray examination of the hands showed some osteoporosis and lack of clear definition of the periosteum, but nothing diagnostic of hyperparathyroidism.

Further $x$-ray films showed neither renal calculi nor nephrocalcinosis, and no changes in the tibiae or clavicles suggestive of Paget's disease. In the lumbar region one vertebra was collapsed and the bones were generally thin in texture, but there were transverse bands of osteosclerosis in one vertebra. The intervertebral spaces were not enlarged.

\section{Treatment}

The diagnosis lay between hyperparathyroidism and hypercalcaemia due to immobility in Paget's disease. The patient was encouraged to exercise herself. Though she walked once with only slight support from nurses early in her stay, no real progress was made until she was given imipramine, $10 \mathrm{mg}$. thrice daily, intramuscularly. Her memory improves, and she became cheerful, talked normally, and could walk short distances when supported.
At this time of increased mobility and improved mental state her plasma calcium was as low as 12.0 and $11.9 \mathrm{mg} . / 100 \mathrm{ml}$. However, despite continued imipramine and while the patient remained alert, the plasma calcium rose again to $13.1 \mathrm{mg} . / 100 \mathrm{ml}$. The absence of an immediate correlation between her mental state and the plasma calcium concentration was also shown during an intravenous infusion of sodium ethylenediamine-tetra-acetate $(3 \mathrm{~g}$. in $200 \mathrm{ml}$. of "normal" saline). Before the infusion the plasma calcium concentration was $13.2 \mathrm{mg} . / 100 \mathrm{ml}$., at the end of the infusion it was $10.3 \mathrm{mg}$., two hours later it had risen again to $11.9 \mathrm{mg}$., and next day was $13.0 \mathrm{mg}$. No change in mental state occurred during or after the infusion.

The effect of cortisone acctate, $50 \mathrm{mg}$. t.d.s. orally, on the plasma calcium concentration was investigated. The calcium concentration was $13.1 \mathrm{mg} . / 100 \mathrm{ml}$. before the steroid was given and did not fall $(13.0,14.2$, and $14.0 \mathrm{mg}$. on the fourth, seventh, and eighth days respectively).

A phosphate excretion test yielded an abnormally high urinary phosphate index of +0.23 (normal range \pm 0.09 ) (tubular phosphate absorption $=72 \%$ of filtered load).

\section{Diagnosis}

Hyperparathyroidism was diagnosed and the neck explored (W.M. K.). At the lower pole of the left lobe of the thyroid a bluish cystic tumour, about $1 \mathrm{~cm}$. in diameter, lay deep to branches of the inferior thyroid artery and superficial to the recurrent laryngeal nerve. No other parathyroid tissue was readily identified on either side of the neck, and, in view of the patient's frail condition and the report of parathyroid adenoma on a frozen section of the tumour, prolonged exploration was not undertaken. An open biopsy of the right iliac crest was done under the same anaesthetic.

The pathologist's report (Dr. W. C. D. Richards) was of a parathyroid adenoma with a small area of normal parathyroid tissue on one aspect. The cells were mostly enlarged chief cells, but there was one small focus of clear cells. There was no suggestion of malignant change. The bone biopsy showed scattered osteoclasts, some of which were in Howship's lacunae. The pattern of the cement lines was normal and gave no indication of Paget's disease. In general, the changes were thought to be like those of hyperparathyroidism.

\section{Progress}

Post-operatively the plasma calcium fell and was $8.2 \mathrm{mg} . / 100 \mathrm{ml}$. 12 days after operation, though calcium gluconate $(12 \mathrm{~g}$. daily) was given orally from the third post-operative day. The plasma phosphate did not rise, but the alkaline phosphatase rose to 97 units and the phosphate excretion index returned to normal at $\mathbf{- 0 . 0 3}$.

The patient became much brighter mentally and could engage in childish repartee, but was again disorientated for place. Chvostek's and Trousseau's signs were never present, and the plasma calcium rose to $9.0 \mathrm{mg} . / 100 \mathrm{ml}$.

She was transferred to Cowley Road Hospital under the care of Dr. L. Wollner. About two months after the operation her memory of events leading up to her admission to hospital returned. She became much more talkative and co-operative, and was able to walk by herself (with a walking-aid) and to sign her own name. Imipramine still improved her mental state. Her plasma calcium remained normal and the alkaline phosphatase fell to $20 \mathrm{~K}$.-A. units. The pelvis and skull showed no change on $x$-ray examination three months after operation.

\section{Discussion}

This case history presents a number of interesting features, some unusual and some well recognized but still apt to mislead in practice.

\section{Mental Disturbance}

Mental disturbance in hyperparathyroidism is well recognized (Nielsen, 1955 ; Karpati and Frame, 1964), but most patients 
present either minor changes in behaviour and mood or coma associated with plasma calcium concentrations of $15 \mathrm{mg}$./ $100 \mathrm{ml}$. or higher. A recent review of the few patients who have shown psychotic features (Karpati and Frame, 1964) described a short period of catatonic stupor three to four days after removal of a parathyroid adenoma from a 48-year-old man. Otherwise catatonia does not seem to have been observed in connexion with either hyperparathyroidism or hypercalcaemia. Catatonia is most often seen in schizophrenia, but can also occur with intracranial disease-for example, neoplasms in the region of the corpus callosum.

\section{Hyperparathyroidism}

This was diagnosed in our patient at an unusually advanced age. A parathyroid adenoma was found by Claude and Schmiergeld (1909) on post-mortem examination of a man who died aged 85 years, and hyperparathyroidism in a patient aged 84 was found at necropsy at the Massachusetts General Hospital (Cope, 1965). Among 323 patients diagnosed at the Massachusetts General Hospital before death there were 20 $(6.2 \%)$ aged 70 or more, the oldest being 83 (Cope, 1965). In two other series the incidence was less than this, and these show how seldom primary hyperparathyroidism is diagnosed in the mid-seventies. Among 138 patients with hyperparathyroidism in the Swedish series of Hellström and Ivemark (1962) there were $3(2.2 \%)$ aged 70 or 71 , and in the same number of patients at University College Hospital $5(3.6 \%)$, all women, were 70 or over, the oldest being 76 (Dent, 1965).

Even when a correct diagnosis of primary hyperparathyroidism has been made in an elderly subject, the patient may not be fit for operation, or the disease may have progressed too far (Gershberg, Jonas, and Stiff, 1962). It is noticeable, too, that in the seven patients at the Massachusetts General Hospital in whom primary hyperparathyroidism was diagnosed only at necropsy, five were aged 71 or more (Cope, 1965). However, it happened that only a few weeks before admission of the patient reported here a 76-year-old woman was admitted under the care of Sir George Pickering and was found to have primary hyperparathyroidism, proved by removal of an adenoma (W.M.K.). She had a more typical history, of renal calculus with pyelonephritis treated by nephrectomy four years previously (with microscopical nephrocalcinosis observed in the removed kidney), and final presentation with vomiting, constipation, and a palpable bone cyst on one tibia.

\section{Hypercalcaemia}

'The most persistent differential diagnosis in our patient was of hypercalcaemia from immobilization in Paget's disease, though a plasma calcium concentration of $14.0 \mathrm{mg} .100 \mathrm{ml}$. would be unusually high for that condition (Reifenstein and Albright, 1944). We have found no report of the response of the plasma calcium concentration to cortisone in an immobilized patient with osteitis deformans, but it seems likely it would fall on treatment with cortisone by analogy with hypercalcaemia in other immobilized subjects. The negative response to the cortisone test and the raised phosphate excretion index were the points most unequivocally in favour of the diagnosis of hyperparathyroidism in the present case.

\section{Forms of Presentation}

Albright, Aub, and Bauer (1934), in a paper which stressed the different ways in which hyperparathyroidism may present, described a form associated with, or masquerading as, Paget's disease. They came to no definite decision between these two alternatives, but made two points of interest to the present case. First, the radiological appearance of osteitis deformans and osteitis fibrosa cystica may be very similar, especially in the pelvis (indeed, because of this the two diseases were once thought to have a common aetiology). They reported two cases of hyperparathyroidism in which the $x$-ray picture of the skull appeared typical of Paget's disease. Secondly, they noticed that bone from the edge of an expanding focus of Paget's disease had the same appearance on histological examination as bone removed in hyperparathyroidism, a finding repeated by Hitchcock and Chater (1962).

It is possible that the present case is one of the coincidence of the two diseases of bone. Certainly it falls into the group described by Albright et al. (1934), and subsequently by Gutman and Parsons (1938) and by Kontos, Kemp, and Sharpe (1962).

\section{Osteosclerosis with Osteoporosis}

Bands of osteosclerosis at the upper and lower margins of a vertebral body, with osteoporosis of the intervening bone ("rugger jersey" spine), have been observed in hyperparathyroidism. At first they were thought to indicate that the hyperparathyroidism was secondary to renal disease (Brookfield, Rubin, and Alexander, 1955) but later they were recorded when a single adenoma was the cause of the parathyroid overactivity (Beveridge, Vaughan, and Walters, 1959 ; Wills, Richardson, and Paul, 1961), but never in the absence of a raised blood-urea concentration. Sclerosis of the margins of vertebrae may occur in Paget's disease and is a possible explanation of the appearance in the present case. If not, it would suggest that the "rugger jersey" spine may occur in hyperparathyroidism in the absence of marked renal failure.

Though there was some mental improvement within a day of operation, the delay of two months before substantial mental improvement and recovery of memory is notable.

\section{Summary}

A woman of 75 with hypercalcaemia from a parathyroid adenoma entered hospital in a catatonic stupor. Her case illustrates the clinical confusion that may arise between hyperparathyroidism and Paget's disease. Her mental state improved markedly two months after removal of the adenoma.

We wish to thank Professor Sir George Pickering, F.R.S., for his kind permission to describe this case.

\section{REFERENCES}

Albright, F., Aub, J. C., and Bauer, W. (1934). f. Amer. med. Ass., $102,1276$.

Beveridge, B., Vaughan, B. F., and Walters, M. N. I. (1959). F. Fac. Radiol. (L.ond.), 10, 197.

Brookfield, R. W., Rubin, E. L., and Alexander, M. K. (1955). Ibid., $7,102$.

Claude, H., and Schmiergeld, A. (1909). C.R. Soc. Biol. (Paris), 56, 131. Cope, O. (1965). Personal communication.

Dent, C. E. (1965). Personal communication.

Gershberg, H., Jonas, S., and Stiff, D. P. (1962). F. Amer. med. Ass. $182,136$.

Gutman, A. B., and Parsons, W. B. (1938). Ann. intern. Med., 12, 13. Hellström, J., and Ivemark, B. I. (1962). Acta chir. scand., Suppl. No. 294.

Hitchcock, H., and Chater, E. H. (1962). F. Irish med. Ass., 51, 156

Karpati, G., and Frame, B. (1964). Arch Neurol. (Chic.), 10, 387

Kontos, H. A., Kemp, V. E., and Sharpe, A. R. (1962). Amer. Practit. 13,620 .

Nielsen, H. (1955). Acta med. scand., 151, 359.

Reifenstein, F. C., jun., and Albright, F.'(1944). New Engl. 7. Med.,

Wills, M. R., Richardson, R. E., and Paul, R. G. (1961). Brit. med. F., 1, 252 . 